\title{
Wahhabi Propaganda in Morocco during the Reign of Sultan Sulayman (1792-1822) as Reflected in the Sources of His Era
}

\author{
Marek M. Dziekan (D)https://orcid.org/0000-0003-0291-2997 \\ Department of Middle East and North Africa \\ Faculty of International and Political Studies \\ University of Łódź \\ mmdziekan@interia.pl
}

\begin{abstract}
Wahhabism is a fundamentalist branch of Islam, which was founded in the eighteenth century. It built its stronghold mainly in the region where it was established, on the Arabian Peninsula. Attempts to spread and gain popularity elsewhere in the Islamic world were made by various rulers from the House of Al Su'ud, but never yielded any great results. One such attempt was a letter sent in 1811 by Abd Allah Ibn Su'ud to the ruler of Morocco, Sulayman (known for adopting Salafi ideas), in which Ibn Su'ud elaborated on the nature of his religious doctrine and encouraged its adoption. These events were described by the most important Moroccan historians of the nineteenth century, including Al-Kansusi, Az-Zayyani, and An-Nasiri. This article is an attempt to recapitulate and arrange these records in order.
\end{abstract}

Keywords: Islam, politics, Wahhabism, Salafism, Morocco, Sultan Sulayman

Słowa kluczowe: islam, polityka, wahhabizm, salafizm, Maroko, sułtan Sulajman

* Article written with the support of the National Science Centre, Poland, project no. 2014/15/B/ HS3/02260. 


\section{Wahhabism - religion and politics}

The founder of Wahhabism ${ }^{1}$ was a Hanbali theologian, Muhammad Ibn Abd al-Wahhab ${ }^{2}$ (1704-1792). He studied theology in Mecca, Medina, and Al-Basra. While studying at these places, he was already starting to teach a new concept of oneness (tawhid). Oneness as formulated by Ibn Abd al-Wahhab was in opposition to any forms of polytheism (shirk) and innovation (bid'a). In accordance with the fundamentalist Hanbali doctrine, he called for a return to the sources of Islam, that is the Quran and Sunna of the Prophet, but, significantly, this return was limited to the hadiths deemed authentic by the Wahhabis. One of the factors that contributed to the emergence of this doctrine was the search for internal forces that could stand up against the rising expansion of the West. Ibn Abd al-Wahhab's thought was puritanical in its nature, and therefore it commanded asceticism in its literal sense; hence the Wahhabi prohibition not just on consumption of alcohol but even coffee. In 1744, he formed an alliance with the strongest Su'ud family in Najd, whose capital was in Ad-Dir'iyya. Thus the force of weaponry was united with an ideology, which paved the way for the creation of the Saudi state in the first half of the twentieth century, with Wahhabism as the ruling and only interpretation of Islam. Until his death, Ibn Abd al-Wahhab taught at the Ad-Dir'iyya mosque and was the political advisor to Emir Muhammad Ibn Su'ud and his successor. Ibn Abd al-Wahhab's main works include Kitab at-tawhid ["The Book of Monotheism/Oneness"], Kitab alusul ath-thalatha wa-adillatuha ["The Book of Three Fundamental Principles and Their Proof"], and Rawdat al-afkar ["Garden of Thoughts"].

\section{Mawlay Sulayman, the Sultan at the turn of the century}

Mawlay Sulayman Abu ar-Rabi Ibn Muhammad ruled 1792-1822. The beginning of his reign was difficult, as he had to grapple with numerous internal problems including opposition from his brother, Hisham, who also declared himself Sultan, but abdicated in 1797. This however, did not end his problems; it was also necessary to subjugate the Berber tribes from the Middle Atlas.

The Sultan was described by the nineteenth century Moroccan historian, Muhammad ad-Du'ayyif in these words: "He had a pleasant appearance, light complexion, he was neither too tall nor too short." ${ }^{33}$ On the other hand, Ali Bey al-Abbasi (whose real name was Domingo Francisco Jorge Badía y Leblich, 1767-1818), a Spanish traveller, soldier, and spy, who lived in Morocco 1803-1805, gave the following

${ }^{1}$ On the Wahhabi doctrine, cf.: W. Ende, Wahhäbiyya, [in:] The Encyclopaedia of Islam, CD-ROM Edition, Leiden 2001; H. Algar, Wahhabism: A Critical Essay, New York 2002; M. bin Abdul-Wahhab, Kitabat-Tauhid, http://www.islambasics.com [access: 29.08.2018].

${ }^{2}$ Cf. H. Algar, op. cit., pp. 5-30; introduction, [in:] M. bin Abdul-Wahhab, op. cit.

${ }_{3}^{3}$ M. ad-Du'ayyif ar-Ribati, Tarikh Ad-Du'ayyif (Tarikh ad-Dawla as-Sa'ida) [The History of AdDu'ayyif (The History of the Fortunate Dynasty)], Ar-Ribat 1986, p. 245. Detailed description of the rule of Sulayman, cf. also A. an-Nasiri, Kitab al-istiqsa li-akhbar duwal Al-Maghrib al-Aqsa [The Book of Investigation about the Dynasties of Morocco], Bayrut 2011, vol. III, pp. 200-266. 
account of his meeting with the ruler: "The sultan, Muley Soliman, appeared to be about forty years old; he is tall and lusty. His countenance has the expression of kindness; it was rather handsome, and not too brown; it was distinguished by large and lively eyes. He spoke fast, and comprehendly [sic] quickly. His dress was very simple, not to say plain, for he was always wrapt [sic] up in a coarse hhaik."4 Sulayman was known for his piety and conservative views. His education was described in quite substantial detail by the contemporary historian, Al-Musharrafi, ${ }^{5}$ who argued he was suitable for the position of a caliph and imam. According to some sources, the Sultan had forty-two children. On the other hand, a very negative account of the Sultan is provided by a Spanish diplomat, Manuel Godoy, who wrote that Mawlay Sulayman was superstitious, stupid, mean, cowardly and cruel; he compared him to Montezuma. ${ }^{6}$ Clearly, there are various differing opinions of Sulayman, but this is not the subject of this paper. The focus is on his religious views-primarily on his Salafite leanings, which were suddenly confronted with attempts by fundamentalist Wahhabi reformists to spread their ideology. In the early nineteenth century, Wahhabi leaders sent out letters throughout the Islamic world in which they encouraged the rulers of various countries to adopt their interpretation of Islam. Around the year $1811^{7}$ such a letter also reached Morocco. In reality, this was the third letter sent between the years 1803-1811, but the first one to merit a reaction from the Sultan. The previous ones remained unanswered. ${ }^{8}$

\section{Historical sources}

The issue examined in this paper was also investigated by, among others, three eminent Moroccan historians who wrote in the nineteenth century. These accounts are directly related to one another.

Chronologically, the first is by Abu al-Qasim az-Zayyani (1734-1833), to whom Brockelmann referred as "the most important historian of the West and the most original writer of his time." "His most significant work is At-Tarjuman al-mu'rib an duwal al-Mashrik wa-al-Maghrib ("A Comprehensive Discourse on the Dynasties of the East and West"), a popular history book published in Tlemcen in 1813. His other work, which is more significant for the context of this article, is a chronicle

${ }^{4}$ D.F.J. Badía y Leblich, Travels of Ali Bey in Morocco, Tripoli, Cyprus, Egypt, Arabia, Syria, and Turkey, Between the Years 1803 and 1807, I, London 1816, p. 56.

${ }^{5}$ M. al-Musharrafì, Al-Hulal al-bahiyya fi muluk ad-dawla al-Alawiyya wa-add ba'd mafakhiriha ghayr al-mutanahiya [Great Robes about the Kings of the Alawite State and a Description of Some of Their Undeniably Famous Deeds], Part II, Ar-Ribat 2005, pp. 37-65.

${ }^{6}$ A. Cánovas del Castillo, Apuntes para la historia de Marruecos, Madrid 1860, p. 150.

7 This year is included here, as [in:] M. El Mansour, Morocco in the Reign of Mawlāy Sulayman, London 1990, p. 140. Source texts reviewed herein do not agree to dates.

${ }^{8}$ Ibidem, p. 139.

${ }^{9}$ C. Brockelmann, Geschichte der arabischen Literatur. Zweiter Supplementband, Leiden 1938, pp. 878-879; cf. É. Lévi-Provençal, Les Historiens des chorfa. Essai sur la littérature historique et biografique au Maroc du XVIe au XXe siècle, Paris 1922, pp. 145-199. 
presented to Sultan Sulayman, titled Ar-Rawda as-Sulaymaniyya ["Sulayman's Garden"], which remains partially in manuscript form until this day. One manuscript is archived at the Maktabat Mu'assasat al-Malik Abd al-Aziz in Casablanca and is available on-line. The modern edition, known as Al-Bustan az-zarif ["A Beautiful Garden"] includes only the first part of the work.

Az-Zayyani is, in turn, quoted by his pupil, Muhammad Ibn Ahmad al-Kansusi, also known as Akansus (1796-1877), a historian, writer, poet, and a makhzan (Moroccan government) clerk, affiliated with the Tijaniyya Sufi order, best known as a poet and author of the historical chronicle Al-Jaysh al-aramram al-khumasi fi dawlat awlad Mawlana Ali as-Sijilmasi ["The Mighty Five-fold Army or on the State of the Sons of Our Lord, Ali as-Sijilmasi"]. Apart from historical prose and poetry, he also dabbled in religious writings, mainly connected with the activities of the Tijaniyya Sufi order, who regard him as one of their most eminent representatives. ${ }^{10}$

The last historian in this chain of recorded accounts, but also the one whose narrative is the starting point here, is Ahmad Ibn Khalid an-Nasiri as-Salawi (1835-1897), a historian, writer and poet, the author of the first comprehensive history of Morocco, published in 1895, Kitab al-istiqsa li-akhbar duwal Al-Maghrib al-Aqsa ["The Book of Investigation about the Dynasties of Morocco"]. He is also the author of other works of a historical and religious nature, including an important work defending a traditional vision of Islam, Ta'zim al-minna fi nusrat as-sunna ["Strengthening of Power in Support of Sunna"], which, interestingly enough, is very popular in modern Saudi Arabia. An-Nasiri is one of the most important representatives of Muslim reformism in its Salafic version in the Western part of the Arab world. ${ }^{11}$

\section{Sultan Sulayman and Wahhabism ${ }^{12}$}

Obviously, these events were reported by the majority of historians from that era. In this paper, the author would like to present the account which is most frequently referred to in modern times, as told by Ahmad Ibn Khalid an-Nasiri. In the Kitab alistiqsa, he writes:

"At that time, ${ }^{13}$ Fas al-Mahrusa also received a letter from Abd Allah Ibn Su'ud alWahhabi, who was active on the Arabian Peninsula and who took over Two Holy Cities for his legal school. The origin of the Wahhabi sect (ta'ifa) is such as described by

${ }^{10}$ Cf. É. Lévi-Provençal, op. cit., pp. 200-213; C. Brockelmann, op. cit., pp. 884-885; M.M. Dziekan, O piśmiennictwie marokańskim w XIX w.: Muhammad Akansūs (1796-1877) - życie i dzieło, "Przegląd Orientalistyczny" 2017, no. 1-2, pp. 45-55.

${ }^{11}$ Cf.: É. Lévi-Provençal, op. cit., pp. 350-368; B. Dennerlein, Entre «restauration» et «réorganisation». L'appropriation savante de la réforme chez Ahmad b. Khâlid an-Nâsirî (m. 1897), [in:] Réformes de l'Etat et réformismes au Maghreb (XIXè-XXè siècles), O. Moreau (ed.), Paris 2009, pp. 197-210; Aḥmad Ibn Hַālid an-Nāṣirī, XIX-wieczne Maroko w Kitāb al-istiqșā, przeł. z j. arabskiego, wstęp, oprac. i przypisy M.M. Dziekan, Łódź 2018.

${ }^{12}$ Quite detailed, measured account of Sulayman's relations with the Wahhabis, cf. M. El Mansour, op. cit., pp. 137-143.

${ }^{13}$ A. an-Nasiri, Kitab al-istiqsa, op. cit., pp. 223-224. 
the author of At-Taribat ash-shafiya ${ }^{14}$ and others: 'A poor Bedouin from Najd, named Sulayman, saw in his dream that from his body there came a flame, and it started to spread and devour everything it came across. He told this dream to one of the dream interpreters, and he said that one of his descendants would create a strong state. The dream came true in his son's son, Sheikh Muhammad Ibn Abd al-Wahhab Ibn Sulayman. ${ }^{15}$ The founder of the school of thought (madhhab) was Muhammad Ibn Abd al-Wahhab, but the name comes from Abd al-Wahhab. ${ }^{16}$ When Muhammad grew up, he enjoyed the respect of the people from his country. Later, he said he was a Qurayshite and came from the People of the Prophet's House. He created the principles of the doctrine which stated that the One God must be worshipped, the Eternal (Qadim), the All-Powerful (Qadir), the Ultimate Truth (Haqq), and the Most Compassionate (Rahman), who rewards the obedient ones and punishes those who defy him. The Quran is also eternal (Qadim) and its tenets must be observed, without delving deep into interpretation. Muhammad is His Prophet and His Beloved, but he should not be praised in panegyric verse, because this is reserved solely for the Eternal. For God the Supreme this is a form of polytheism, which must be avoided in order for man to walk the right path. Those who accept these principles are the real worshippers; those who do not observe them, should be killed. These are the basics of his doctrine. Initially, he spread them in secret, and people began to imitate him. Then he went to Syria with the same purpose in mind. However, when he did not find support there, he returned to the Arabian Peninsula after three years of absence.' ${ }^{17}$

When he returned, he contacted one of the Bedouin sheikhs from Najd called Abd Allah Ibn Su'ud, an energetic man of noble heart, who supported him and endorsed his doctrine. He fought on his behalf until, finally, they divided the leadership between themselves - himself and Muhammad Ibn Abd al-Wahhab. Ibn Abd al-Wahhab devoted himself to religious matters, and Ibn Su'ud became a Wahhabi emir and an army commander. Their cause gradually spread until they seized Al-Hijaz, Two Holy Mosques, and the entire Arabian Peninsula." Then, says the author of At-Taribat ashshafiya: "The Wahhabi mosques are devoid of minarets, domes or any other decorations. They do not revere the imams or holy men (wali). They bury their dead without erecting large graves (mashhad) and do not turn the burial into a celebration. They eat barley flatbread, dates, and locusts, but fish, meat, and rice only occasionally. They do not drink coffee and their clothing and houses are devoid of decorations." 18

${ }^{14}$ R.R. at-Tahtawi (1801-1873), Egyptian scholar, writer, reformer of higher education, author of many works which were breakthroughs for the reform of Islam at the end of the nineteenth century. AnNasiri quotes his book At-Taribat ash-shafiya li-murid al-jughrafya [The Unequivocal Arabization Approach to Geography] from 1838. The title is related in some sources as At-Tarifat... [Full Definitions...], e.g. Kh.D. az-Zirikli, Al-Alam [Names], Bayrut 1989, vol. III, p. 29.

${ }^{15}$ Lived 1703-1792; cf. H. Laoust, Ibn 'Abd al-Wahhāb, [in:] The Encyclopaedia of Islam, CD-ROM Edition v.1.1., Leiden 2001; H. Algar, op. cit., pp. 5-30; D. Commins, The Wahhabi Mission and Saudi Arabia, London 2006, passim.

16 The issue here is that Abd al-Wahhab was the father of Muhammad, the founder of the branch, and had nothing to do with this faction, but its name comes from his surname.

${ }^{17}$ R.R. at-Tahtawi, op. cit., pp. 177-178; inaccurate quotation.

18 Ibidem, p. 179. 
When Ibn Su'ud took the Two Holy Cities, he sent out letters far and wide - to Iraq, Syria, Egypt, and the Maghreb, calling on the faithful to adopt his doctrine. When a letter from him arrived in Tunis, the mufti there sent a copy of it to scholars in Fez, and a response was written by the alim, sheikh, and adib, Abu al-Fayd Hamdun Ibn al-Hajj. ${ }^{19}$

The author of Al-Jaysh said that the Sheikh Abu al-Fayd's response was written as ordered by the Sultan and on his behalf. This response was sent through his son, Mawlay Ibrahim Ibn Sulayman, when he was performing the Hajj. I said: "And that means that the letter from Ibn Su'ud came directly to the Sultan Mawlay Sulayman, and it was not a copy, such as was sent to him through the alims of Tunis. And God knows best."

The letter referenced above was sent to Sulayman by Abd Allah Ibn Su'ud, who died in 1818, who was also the Wahhabi's imam until 1814 and was the last ruler of the Emirate of Dir'iyya.

An-Nasiri writes further:

"That year, that is in the year 1226, ${ }^{20}$ the Sultan Mawlay Sulayman sent his son, the esteemed (al-ustadh al-afdal) Mawlay Abu Ishaq Ibrahim Ibn Sulayman to AlHijaz, so that he could perform the Hajj [...].

The author of Al-Jaysh said that Mawlay Ibrahim went to perform the Hajj and took the Sultan's response with him. As a result, many matters connected with the Hajj were resolved, both for them as well as for those who joined them from the East and the West. They performed all rites in peace and safety.

And he wrote further: 'Numerous people told me, those who went on the pilgrimage with Mawlay Ibrahim that year, that they did not see in the Sultan, that is in Su'ud, that which would be against their legal knowledge. But they did see in him and his acolytes that they closely follow the principles of Islam - prayer, ritual cleanliness and fast, banning that which is forbidden. Both Holy Places were cleansed of the wicked deeds committed there openly, without condemnation from anyone. They also said that the ruler looked just as anyone else - he did not distinguish himself from his subordinates either by clothing or a better mount. When he met with the sharif, Mawlay Ibrahim, he paid him respect due to a member of a Noble House. He sat down with him as if with one of his own people. On our side, the conversation was led by the qadi and faqih, Abu Ishak Ibrahim az-Zadaghi. ${ }^{21}$

${ }^{19}$ Lived 1760-1817, one of the most eminent alims and adibs of his time, author of many works on theology and Islamic law, cf. Kh.D. az-Zirikli, op. cit., vol. II, p. 275.

${ }^{20}$ That is 27.01.1811-15.01.1812 CE. A. an-Nașiri, op. cit., p. 225. Acc. to M. al-Kansusi, Al-Jaysh al-aramram al-khumasi fi daw lat awlad Mawlana Ali as-Sijilmasi, Marrakesh 1994, vol. 1, p. 289, this was year 1227, but this is Al-Kansusi's mistake, because he is quoting Az-Zayyani (A.Q. az-Zayyani, $A r$ Rawda as-Sulaymaniyya, the manuscript of Maktabat Mu'assasat Malik Ibn Abd al-Aziz, Ad-Dar al-Bayda, available on-line: https://archive.org/details/rawda_solaymania-zayani, p. 249 [access: 12.02.2016], which explicitly states the year 1226; cf. C.-A. Julien, Le Maroc face aux impérialismes 1415-1956, Paris 2011, pp. 26-27.

${ }^{21}$ Died 1834; he was a supporter of Wahhabi ideas, which caused some problems for him in Morocco; cf. A.S. Ibn Suda, Ithaf al-mutali [Treasury for the reader], Bayrut 1997, vol. I, p. 156. 
The words of Ibn Su'ud can be summarised as follows:

'People think, he said, that we are rising against Muhammad's Sunna. Have you ever seen us defy the Sunna in any way? What have you heard about us, before we met here?'

The qadi responded to that:

'We heard that you say that God materially sits on His throne.'

He responded thus:

'God forbid! We claim, as in Malik's words: that it is known that he sits on the Throne, what is unknown is how. This question is an innovation (bid'a). Is that something against the Sunna?'

They answered:

'No. And so say we.'

Then the qadi said to him,

'We also heard that you say that neither the Prophet Muhammad, prayer and peace be unto Him, nor other prophets live in their graves.'

When he heard the Prophet's name, prayer and peace be unto Him, he raised his voice in prayer in His name and answered,

"God forbid! We claim that in His grave and in the graves of other prophets there is life of a higher order than the life of martyrs."

Then the qadi said,

"We also heard that you forbid from visiting His grave and the graves of all deceased, invoking the collections of true hadith, whose authenticity cannot be disproved."

He replied,

"God forbid us from rejecting a tenet written into our law. And have we forbidden you from doing this, knowing that you are rational people and are aware of what you are doing and why you are doing it? We forbid it for commoners ( tice polytheism and ask the deceased for favours, which only God the Supreme can grant. The aim of such a visit should be to make the visitor aware of the state of the deceased and realise their own path which they are treading. Then, they should ask God the Supreme to forgive the deceased their sins, if the deceased is worthy to earn God's grace. This is the opinion of our imam, Ahmad Ibn Hanbal; may God rejoice in him. But we see that the commoners do not understand this, thus we forbade them from visiting the graves to root out evil. So how do we defy the Sunna?"

Then the author of Al-Jaysh said, "And that is what happened and this was what we heard from the people who were there. Later we also asked others in private and everyone confirmed it."22

An-Nasiri bases this account, as he himself states, on the work of Muhammad alKansusi, ${ }^{23}$ whose account was not quoted verbatim but rather abridged; only a small fragment of the passage is a direct quote. However, the description of Wahhabism in 1838, which An-Nasiri quotes after At-Tahtawi, is unfamiliar to Al-Kansusi. In turn,

${ }^{22}$ Inaccurate quote from M. al-Kansusi's work, cf. op. cit., pp. 290-292. A.Q. az-Zayyani, op. cit., pp. 250-251,

${ }^{23}$ M. al-Kansusi, op. cit., pp. 290-292. 
Al-Kansusi bases his version on a fragment from the work of his teacher, Az-Zayyani, Ar-Rawda as-Sulaymaniyya. What is interesting, in his most important work AzZayyani devoted only a short, one-sentence remark to this matter, one that concerned Ibrahim's Hajj, and he did not mention the Wahhabi's letter at all. ${ }^{24}$ In his record, AnNasiri did not provide the date of the event, not even the year, and introduced the narrative enigmatically with the phrase "at that time," although the date was mentioned by both earlier sources cited by the author. The date was disclosed in another account.

None of the historians mentioned here discussed a very important fact-that other eminent Moroccan alims wrote replies to the Wahhabi's letter: Ibn Kiran (1760 1817), who was part of a delegation sent by the Sultan to Al-Hijaz, and Sulayman al-Hawwat (1747-1816). The answer from Abu al-Fayd, known better as Ibn al-Hajj, was written in poetic form. According to Mohamed El Mansour, the author of a monograph devoted to Sulayman, Ibn al-Hajj's poem was only a form of eulogy and annex to the text proper, ${ }^{25}$ although it contained the most important factual elements as well. These texts, as far as the author of this paper is aware, have remained in manuscript form until this day and have never been the subject of a serious, scientific edition. Only the response from Ibn Kiran is available on-line, on the Tijaniyya order web page ${ }^{26}$ and in an article by Muhammad al-Mahdi al-Kansusi devoted to these events. ${ }^{27}$ The latter is, however, an abridged version, because the entire account was several dozen pages long ("four pamphlets" - arba'at kararis). The responses of the three theologians reflect the views of the Sultan himself, who was also very familiar with the problems of Muslim theology, but they also contain threads with their own opinions.

The most important theological matters which were elaborated on in Ibn Kiran's letter and the other responses are alluded to in the conversation quoted above. The salient point concerned all the forms of worship of graves. In this case, Sulayman's views were similar to the Wahhabi ideas - this is clearly visible in Sulayman's opposition to worshipping the so-called Muslim saints, awliya, or even ancestors - in 1805, the Sultan himself ordered the removal of a mausoleum in Rabat, where the ashes of his father were interred, leaving only the grave; then, a year later, he wrote a treatise criticising Sufi practices, which in Morocco, where Islam is steeped in Maraboutism, obviously could not be greeted enthusiastically. The author of the paper points to these dates, as they prove that it is difficult to speak of any explicit impact of the Wahhabi doctrine on Sulayman's views, while the opposite is very often ascribed to him. The two previous letters from the Wahhabis could indicate this more clearly, but, as far as the author knows, they have not survived till today. He was undoubtedly

${ }^{24}$ A.Q. az-Zayyani, At-Tarjuman al-mu'rib an duwal al-Mashriq wa-al-Maghrib = Aboulgasem ben Ahmed Ezziâni, Le Maroc de 1631-1812, extrait de l'ouvrage intitulé Et Tordjeman el Moarib publié et trad. par O. Houdas, Paris 1886, Arab. p. 104, French p. 193.

${ }^{25}$ M. El Mansour, op. cit., p. 141.

${ }^{26}$ Risalat as-sultan Mawlay Sulayman ila amirMakka Su'ud wa-sharikihi fi al-haraka [The letter of the Sultan Mawlay Sulayman to the emir of Mecca and his fellows in the movement], http://www. tidjania.fr/lettres-amis/305-my-solaymane [access: 04.08.2017].

${ }_{27}$ M.M. al-Kansusi, Bidayat al-haraka al-wahhabiyya [Beginnings of the Wahhabi movement] 2/2, http://tamazirtpress.net/news4361.html [access: 04.08.2017]. 
a conservative Maliki and his views were far from the extreme ideas of the Hanbali school. This confirms the fact that during that time, the Wahhabi doctrine was not very well known in the Maghreb. ${ }^{28}$ Of course, some rumours about the Wahhabis would have reached Morocco, brought by pilgrims, but it was the dispute described in the paper that made the Moroccans fully aware of the existence and sense of Wahhabism. The text quoted above and the responses written by Ibn Kiran show that the Moroccans did not regard the Wahhabis as any significant threat; one could even say that they spoke very well of their lifestyles (pointing to the simplicity and modesty that characterised early Wahhabism and preferred by Sultan Sulayman himself); they also indicated the absence of any essential contradictions between their own views and sharia in the Wahhabi version of Islam. It is worth noting that there is nothing disrespectful of Wahhabism in the quote from the book by the Egyptian At-Tahtawi cited by An-Nasiri.

However, in the case of the Moroccans, the details caused Ibn Kiran to deem Wahhabism an innovation - bid'a, while Al-Hawwat considered them "rebels," ${ }^{29}$ who threaten the safety of pilgrims. The gentlest critique definitely came from Ibn al-Hajj, and a lot points to his text being the best reflection of Sulayman's views. However, as it is clear today, this did not make Wahhabism popular in Morocco at all. Sulayman did not press this matter, being quite aware of the specific nature of Islam practised by his subjects. He kept his sympathies close to his chest and did not reveal them much. As the author of this paper mentioned earlier, there are varying opinions on the reign of the Sultan. Some historians, especially Western historians, claim that Sulayman was not very popular among his subjects. Possibly he was aware of it, and this contributed to curtailing Wahhabi influence in the Maghreb. During the reign of Sulayman's successor, such influences were completely absent, and the worship of "saints" was openly opposed only by Sultan Hasan (ruled 1873-1894).

\section{References}

Algar H., Wahhabism: A Critical Essay, New York 2002.

Badía y Leblich D.F.J., Travels of Ali Bey in Morocco, Tripoli, Cyprus, Egypt, Arabia, Syria, and Turkey, between the Years 1803 and 1807, London 1816.

bin Abdul-Wahhab M., Kitab at-Tauhid, http://www.islambasics.com [access: 29.08.2018].

Brockelmann C., Geschichte der arabischen Literatur. Zweiter Supplementband, Leiden 1938.

Cánovas del Castillo A., Apuntes para la historia de Marruecos, Madrid 1860.

Commins D., The Wahhabi Mission and Saudi Arabia, London 2006.

Dennerlein B., Entre «restauration» et «réorganisation». L'appropriation savante de la réforme chez Ahmad b. Khâlid an-Nâsirî (m. 1897), [in:] Réformes de l'Etat et réformismes au Maghreb (XIXè-XXè siècles), O. Moreau (ed.), Paris 2009, pp. 197-210.

Ad-Du'ayyif ar-Ribati M., Tarikh Ad-Du'ayyif (Tarikh ad-dawla as-sa'ida), ed. A. al- Amārī, ArRibat 1986.

${ }^{28}$ Cf. M. El Mansour, op. cit., p. 138.

${ }^{29}$ As the text by Al-Hawwat is unavailable, the author used the work by El Mansour, who uses the term rebels, op. cit., p. 141. 
Dziekan M.M., O piśmiennictwie marokańskim w XIX w.: Muhammad Akansūs (1796-1877) życie i dzieło, "Przegląd Orientalistyczny" 2017, no. 1-2, pp. 45-55.

El Mansour M., Morocco in the Reign of Mawlāy Sulayman, London 1990.

Ende W., Wahhäbiyya, [in:] The Encyclopaedia of Islam, CD-ROM Edition, Leiden 2001.

Julien Ch.-A., Le Maroc face aux impérialismes 1415-1956, Paris 2011.

Ibn Suda A.S., Ithaf al-mutali, Bayrut 1997.

Al-Kansusi M., Al-Jaysh al-aramram al-khumasi fi dawlat awlad Mawlana Ali as-Sijilmasi, Marrakush 1994.

Al-Kansusi M. al-Mahdi, Bidayat al-haraka al-wahhabiyya 2/2, http://tamazirtpress.net/news4361. html [access: 04.08.2017].

Laoust H., Ibn 'Abd al-Wahhāb, [in:] The Encyclopaedia of Islam, CD-ROM Edition v.1.1., Leiden 2001.

Lévi-Provençal É., Les Historiens des chorfa. Essai sur la littérature historique et biografique au Maroc du XVIe au XXe siècle, Paris 1922.

Al-Musharrafi M., Al-Hulal al-bahiyya fi muluk ad-dawla al- 'ala wiyya wa- 'add ba 'd mafakhiriha ghayr al-mutanahiyya, Part II, Ar-Ribat 2005.

An-Nasiri Ibn Khalid A., Kitab al-istiqsa li-akhbar duwal al-Maghrib al-Aqsa, Bayrut 2011.

An-Nāṣirī A.I.H. zypisy M.M. Dziekan, Łódź 2018.

Risalat as-sultan Mawlay Sulayman ila amir Makka Su'ud wa-sharikih fi al-haraka, http://www. tidjania.fr/lettres-amis/305-my-solaymane [access: 04.08.2017].

At-Tahtawi R.R., At-Taribat ash-shafiya li-murid al-jughrafya, Al-Kahira 1838.

Az-Zayyani A.Q., Ar-Rawda as-Sulaymaniyya, https://archive.org/details/rawda_solaymania-zayani [access: 12.02.2016].

Az-Zayyani A.Q., At-Tarjuman al-mu'rib an duwal al-Mashriq wa-al-Maghrib = Ezziâni A.b.A., Le Maroc de 1631-1812, extrait de l'ouvrage intitulé Et Tordjeman el Moarib publié et trad. par O. Houdas, Paris 1886.

Az-Zirikli Kh.D., Al-Alam, Bayrut 1989. 